\title{
Control of early ovarian follicular development
}

\author{
K. P. McNatty ${ }^{1}$, D. A. Heath ${ }^{1}$, T. Lundy ${ }^{1}$, A. E. Fidler ${ }^{1}$, \\ L. Quirke ${ }^{1}$, A. O'Connell ${ }^{1}$, P. Smith ${ }^{1}$, N. Groome ${ }^{2}$ and \\ D. J. Tisdall ${ }^{3}$
}

'Wallaceville Animal Research Centre, PO Box 40063, Upper Hutt, New Zealand; ${ }^{2}$ Oxford Brookes University, Gipsy Lane, Headington, Oxford, OX3 OBP, UK; ${ }^{3}$ Virus Research Unit, Department of Microbiology, University of Otago, PO Box 56, Dunedin, New Zealand

\begin{abstract}
Early follicular growth refers to the development of an ovarian follicle from the primordial to early antral phase. In sheep and cows these phases of growth can be classified by the configuration of granulosal cells in the largest cross-section of the follicle as types 1 (primordial), 1a (transitory) 2 (primary), 3 and 4 (preantral) and 5 (early antral). Follicles classified as type 1 may be highly variable within each species with respect to number of granulosal cells and diameter of oocyte. Much of the variation in granulosal cell composition of type 1 follicles may occur at formation and this may account for the variability in granulosal cell composition throughout subsequent stages of growth. There appear to be important differences among species (for example sheep and cattle) in the number and function of granulosal cells relative to the diameter of the oocyte during the initiation of follicular growth. There is evidence that most, if not all, of the growth phases from types 1 to 5 are gonadotrophin-independent and that follicles develop in a hierarchical manner. In sheep, cows and pigs, numerous growth factor, growth factor receptor and gonadotrophin receptor mRNAs and peptides (for example c-kit, stem cell factor, GDF-9, $\beta_{B}$ and $\beta_{A}$ activin/inhibin subunit, $\alpha$ inhibin subunit, follistatin, FGF-2, EGF, EGF-R, TGF $\beta_{1, \text { and } 9}$ FSH-R and LH-R) are expressed in a phase of growth (for example types 1-5)-specific and cell-specific manner. However, the roles of many of these factors remain to be determined.
\end{abstract}

\section{Introduction}

The aim of this review is to describe the localization of growth factors and receptors for both growth factors and gonadotrophins during the development of an ovarian follicle from the primordial to early antral phase of growth. Particular emphasis is focused on current understanding of early follicular growth in domestic ruminants. Where appropriate some references to the extensive literature in other species is included.

\section{Classification of Early Follicular Growth Stages}

A classification system for small bovine follicles was described by Braw-Tal and Yossefi (1997). In this classification system preantral follicles and the smallest antral follicles are classified as types 1-5: type 1 refers to primordial follicles (one layer of 'flattened' granulosal cells, granulosal cell), type 1a to transitory follicles (one layer of cells that are a mixture of 'flattened' and cuboidal granulosal cell), type 2 to primary follicles (one or two layers of cuboidal granulosal cells), type 3 to small preantral (two to four layers of granulosal cells), type 4 to large preantral (four to six layers of granulosal cells) and type 5 to small antral follicles (more than five layers of granulosal cells). The inclusion of type 1a follicles acknowledges the finding that in cows $82.5 \%$ of the follicle population with one layer of 
Table 1. Classification and characterization of small ovine follicles

\begin{tabular}{|c|c|c|c|c|c|c|}
\hline Follicle (type) & $n$ & $\begin{array}{c}\text { Layers of } \\
\text { granulosal cells } \\
\text { (shape) }\end{array}$ & $\begin{array}{l}\text { Number of } \\
\text { granulosal cells } \\
\text { in largest } \\
\text { cross-section }\end{array}$ & $\begin{array}{l}\text { Total number of } \\
\text { granulosal cells } \\
\text { in follicle }\end{array}$ & $\begin{array}{c}\text { Oocyte } \\
\text { diameter } \\
(\mu \mathrm{m})\end{array}$ & $\begin{array}{c}\text { Follicle } \\
\text { diameter } \\
\text { ( } \mu \mathrm{m})\end{array}$ \\
\hline $\begin{array}{l}\text { Primordial } \\
\text { (1) }\end{array}$ & 195 & $\begin{array}{c}1 \\
\text { (all flattened) }\end{array}$ & $\begin{array}{c}4^{\mathrm{a}} \\
(1,11)\end{array}$ & $\begin{array}{c}16^{\mathrm{a}} \\
(3,52)\end{array}$ & $\begin{array}{c}34.6^{\circ} \\
(22.8,52.3)\end{array}$ & $\begin{array}{c}40.8^{a} \\
(28.1,60.5)\end{array}$ \\
\hline $\begin{array}{l}\text { Transitory } \\
\text { (1a) }\end{array}$ & 53 & $\frac{1}{\text { (one or more cuboidal) }}$ & $\begin{array}{c}9^{b} \\
(4,18)\end{array}$ & $\begin{array}{l}39^{\mathrm{b}} \\
(9,136)\end{array}$ & $\begin{array}{c}40.6^{\mathrm{b}} \\
(27.3,53.0)\end{array}$ & $\begin{array}{c}50.8^{6} \\
(37.3,64.0)\end{array}$ \\
\hline $\begin{array}{l}\text { Primary } \\
\text { (2) }\end{array}$ & 109 & $\begin{array}{c}1-2 \\
\text { (all cuboidal) }\end{array}$ & $\begin{array}{c}19 c \\
(3,49)\end{array}$ & $\begin{array}{c}128 \mathrm{c} \\
(30,520)\end{array}$ & $\begin{array}{c}52.1^{c} \\
(31.0,80.0)\end{array}$ & $\begin{array}{c}75.2 \\
(49.7,118.8)\end{array}$ \\
\hline $\begin{array}{l}\text { Small preantral } \\
\text { (3) }\end{array}$ & 38 & $>2-4$ & $\begin{array}{c}64^{\mathrm{d}} \\
(19,152)\end{array}$ & $\begin{array}{c}637^{d} \\
(127,2174)\end{array}$ & $\begin{array}{c}72.9^{d} \\
(40.6,92.0)\end{array}$ & $\begin{array}{l}128.5^{4} \\
(63.5,191.0)\end{array}$ \\
\hline $\begin{array}{l}\text { Large preantral } \\
\text { (4) }\end{array}$ & 18 & $>4-6$ & $\begin{array}{c}187 \\
(116,308)\end{array}$ & $\begin{array}{c}2104^{e} \\
(1090,3464)\end{array}$ & $\begin{array}{c}87.8^{\circ} \\
(76.9,100.2)\end{array}$ & $\begin{array}{c}194.1^{\mathrm{e}} \\
(164.2,256.3)\end{array}$ \\
\hline $\begin{array}{l}\text { Small antral } \\
\text { (5) }\end{array}$ & 23 & $>5$ & $\begin{array}{c}475^{f} \\
(199,1128)\end{array}$ & $\begin{array}{l}11649^{f} \\
(3425,51447)\end{array}$ & $\begin{array}{c}118.8^{f} \\
(90.9,141.6)\end{array}$ & $\begin{array}{c}326.9^{i} \\
(191.5,450.0)\end{array}$ \\
\hline
\end{tabular}

Values are geometric means (and ranges). Values in columns not sharing a common alphabetical superscript are significantly different $\left(P<0.05\right.$. ANOVA on $\log _{\mathrm{e}}$ transformed data). Data from Lundy et al. (1999).

Table 2. Expression of growth factors and receptors during early follicular growth in sheep

\begin{tabular}{|c|c|c|c|c|c|c|c|c|c|c|c|c|}
\hline Cell type & & C-kit & SCF & $\begin{array}{c}\beta_{\mathrm{a}} \text { activin/ } \\
\text { inhibin }\end{array}$ & FSHR & $\alpha$-Inhibin & Follistatin & $\begin{array}{c}\beta_{\mathrm{B}} \text { activin/ } \\
\text { inhibin }\end{array}$ & & $\begin{array}{l}G F \beta \\
2 / 3\end{array}$ & $\mathrm{FGF}_{2}^{+}$ & LHR \\
\hline \multicolumn{13}{|l|}{ Granulosal } \\
\hline \multirow[t]{6}{*}{ Follicle type } & 1 & & - $\odot$ & & & & & $\odot$ & & & & \\
\hline & 1a & & - $\odot$ & - 0 & & & & $\odot$ & & & & \\
\hline & 2 & & - $\odot$ & - 0 & $\bullet \odot$ & & $\odot$ & (c) & (c) & $\odot$ & $\odot$ & \\
\hline & 3 & & $\bullet$ & - 0 & - • & $\bullet$ & - $\odot$ & ๑) & $\odot$ & $\odot$ & $\odot$ & \\
\hline & 4 & - $\odot$ & - & - 0 & $\bullet \odot$ & $\bullet$ & - $\odot$ & $\odot$ & $\odot$ & $\odot$ & $\odot$ & \\
\hline & 5 & $\bullet \odot$ & - $\odot$ & -0 & - $\odot$ & - & - $\odot$ & $\bullet \odot$ & $\odot$ & $\odot$ & $\odot$ & \\
\hline Oocyte & & $\begin{array}{l}\bullet \\
(1-5)\end{array}$ & $\stackrel{\odot}{\odot}$ & 0 & & & $\odot$ & • & (c) & $\odot$ & $\stackrel{\odot}{\odot}$ & \\
\hline $\begin{array}{l}\text { Theca } \\
\text { interna }\end{array}$ & & & & & & & & & - $\odot$ & - $\odot$ & $\odot$ & $\begin{array}{l}-0 \\
(4-5)\end{array}$ \\
\hline
\end{tabular}

- $\mathrm{mRNA}$; , protein; 0 , localized increasingly in oocyte plasma membrane and zona pellucida

()$=$ follicle type in which expression is observed, 'Data from studies in cows, SCF = stem cell factor

granulosal cells has a least one cuboidal granulosal cell (317 follicles examined; van Wezel and Rogers, 1996). In ewes a similar analysis revealed that $24.2 \%$ of follicles with one layer of granulosal cells ( $n=215$ follicles) contained one or more cuboidal cells (Lundy et al., 1998). A classification system for small ovarian follicles in the ewe is shown in Table 1.

The results for primordial follicles in ewes with respect to oocyte diameter and the number of granulosal cells in the largest cross-section are similar to those for cows (Braw-Tal and Yossefi, 1997). The total number of granulosal cells around the oocyte in the ewe was determined using the nucleator and fractionator techniques of Gundersen (1988). The total population of granulosal cells in primordial follicles together with oocyte diameter are highly variable (Table 1 ). The variability in granulosal cells in type 1 follicles may arise at the time when follicles are first forming (Hirshfield and De Santi, 1995). There appear to be important differences among species (for example between sheep and cattle) in both the number and activity of granulosal cells relative to the diameter of the oocyte during the initiation of follicular growth (Braw-Tal and Yossefi, 1997; Lundy et al., 1998). In 

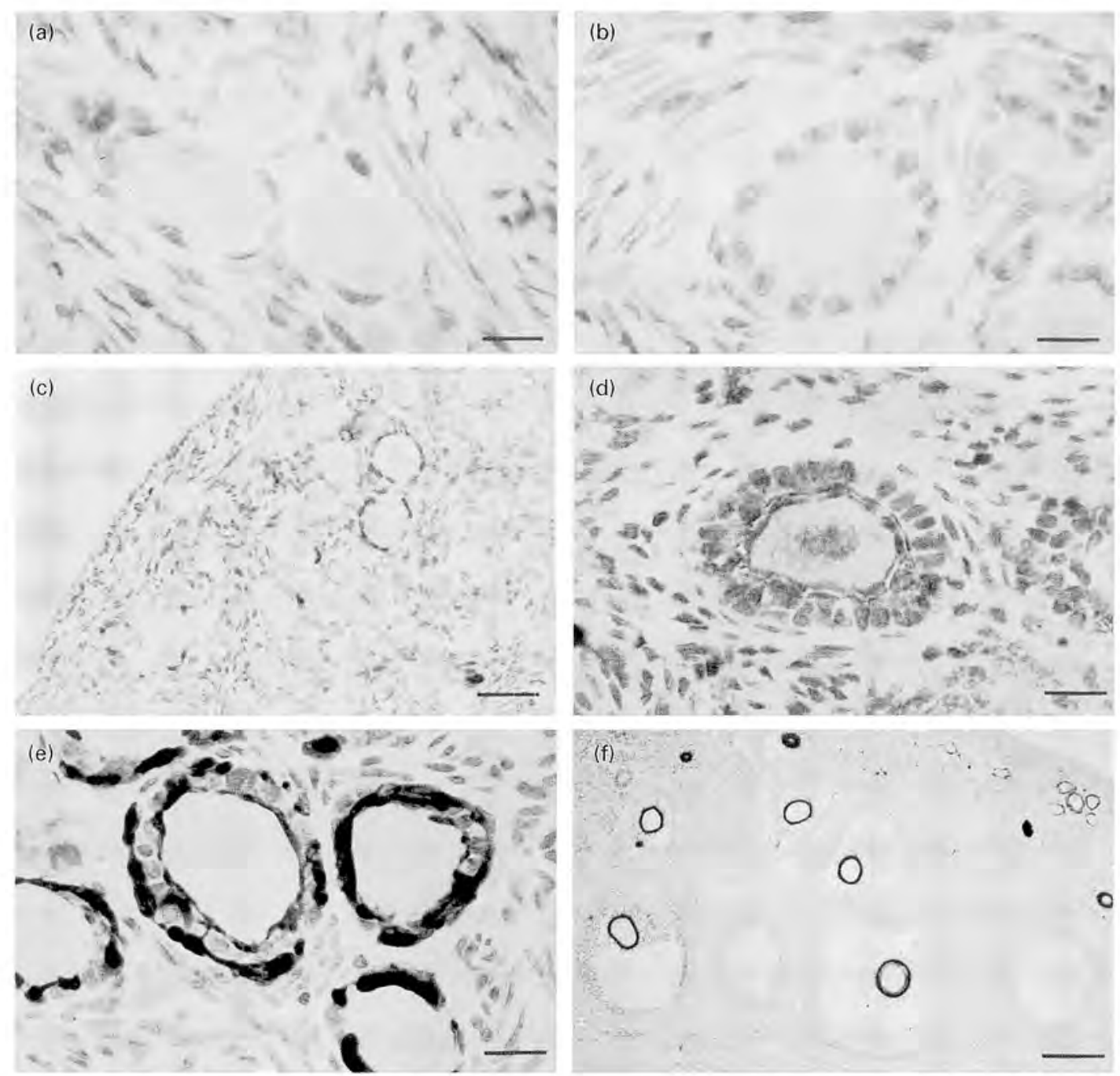

Fig. 1. Immunostaining for growth factor receptors or growth factors in ovarian follicles of the sheep ovary: (a) c-kit localized in oocytes of type 1 and 1a follicles and (b) in an oocyte of a type 2 follicle; (c) stem cell factor (SCF) localized to granulosal cells of type 1 follicles and (d) the oocyte and granulosal cells of a type 2 follicle; (e) inhibin $\beta_{\mathrm{B}}$ localized to granulosal cells of type 1a and 2 follicles and $(\mathrm{f})$ zona pellucida of larger preantral and antral follicles. All immunostaining was performed with paraformaldehyde fixed paraffin wax embedded $5 \mu \mathrm{m}$ sections. All immunostaining was blocked when the antibodies were either preincubated with their respective antigens or replaced by non-immune serum. The immunohistochemical procedures used were those described by Hsu et al. (1981). The c-kit antibody (C19) was supplied by Santa Cruz Biotechnology Inc, Santa Cruz (CA). The stem cell factor antibody (RGAS005) and recombinant ovine stem cell factor $(+1$ to +206 amino acid sequence RGAS006) were generated at the Wallaceville Animal Research Centre. Inhibin $\beta_{B}$ antibody was clone C5 described in Groome et al. (1996). Scale bars represent (a) and (b) $13.3 \mu \mathrm{m}$, (c) $40 \mu \mathrm{m}$, (d) $16 \mu \mathrm{m}$, (e) $16 \mu \mathrm{m}$ and (f) $160 \mu \mathrm{m}$.

cows and rats, very few granulosal cells in type 1 follicles immunostain for proliferating cell nuclear antigen (PCNA), an essential nuclear protein involved in cell proliferation (Oktay et al, 1995; Wandji et al., 1996a). By contrast in ewes, about $30 \%$ or more of the granulosal cells in type 1 follicles immunostain for PCNA (Lundy et al., 1998). Therefore a key question that remains unanswered is 

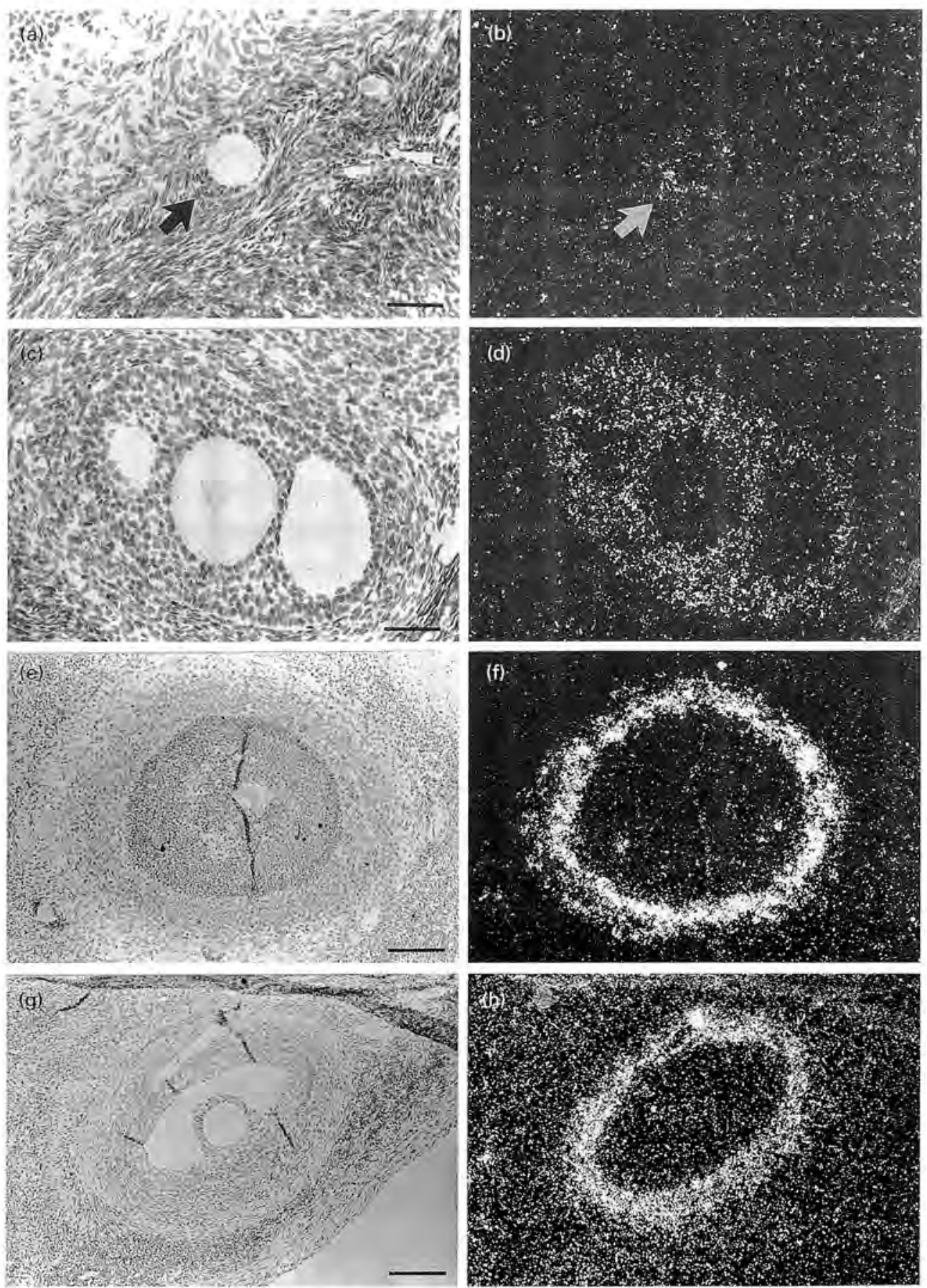

Fig. 2. Localization of gonadotrophin receptor mRNAs in small follicles of the sheep ovary: (a) light field and (b) dark field views of a type 1 and type 3 follicle with evidence of hybridization of ${ }^{33} \mathrm{P}$ labelled FSH-receptor antisense riboprobe to granulosal cells of the type 3 (arrowed) but not type 1 follicle; (c) light field and (d) dark field views of a type 5 follicle showing hybridization of the FSHreceptor antisense riboprobe to granulosal cells; (e) light field and (f) dark field views of ${ }^{33} \mathrm{P}$-labelled $\mathrm{LH}$ receptor antisense riboprobe hybridized to theca interna of a type $4-5$ follicle; (g) light field and (h) 
whether type 1 follicles are a pool of quiescent follicles. Compared with the uncertainty about the growth status of type 1 follicles, the collective evidence from several species is that type 1a follicles: have entered the growth phase. In cows, ewes and rats, cuboidal granulosal cells in type 1a follicles may immunostain for PCNA or incorporate tritiated thymidine (Oktay et al., 1995; Wandji et al., 1996a; Braw-Tal and Yossefi, 1997; Lundy et al., 1998). Moreover in ewes, type 1a follicles contain significantly more granulosal cells and the mean oocyte diameters are larger compared with type 1 follicles (Table 1). As ovine follicles transit through the types 1 to 3 growth phases, the mean total number of granulosal cells undergo at least six doublings before entering the type 4 phase which in turn may include two doubling cycles. Thus when considering factors that might regulate early follicular growth it may be important to consider: (i) the classification system being used; (ii) the animal model being studied; (iii) whether type 1 follicles are all quiescent follicles and; (iv) the likelihood that types 2,3 and 4 follicles each represent more than one cell-doubling cycle with the possibility that each cycle is under some form of regulatory control. It is suggested that future studies need to focus more closely on the characteristics of the types of follicle being studied. Some of the growth regulatory factors associated with these early phases of growth are discussed below (see also Table 2).

\section{Growth Factors and Receptors}

\section{C-kit/Stem cell factor}

The tyrosine kinase receptor c-kit and its ligand, stem cell factor (SCF), have been localized to oocytes and granulosal cells, respectively (Motro and Bernstein, 1993). In the mouse, inhibition of the interaction between SCF and c-kit prevents the transformation of primordial follicles to primary follicles without blocking the formation of primordial follicles (Huang et al., 1993; Yoshida et al., 1997). In the sheep ovary, SCF mRNA has been detected in granulosal cell and c-kit mRNA in the oocyte at all stages of follicular growth from the primordial phase (Clark et al., 1996; Tisdall et al., 1997). Furthermore, in sheep, c-kit protein can be localized to oocytes of primordial and growing follicles and SCF protein to granulosal cells and oocytes of both primordial and primary follicles (Fig. 1). These findings are consistent with the view that activation of the c-kit tyrosine kinase system by SCF is an important factor in the growth of primordial follicles. One interesting finding from the study of Yoshida et al. (1997) was that the granulosal cell ceased to proliferate after the administration of c-kit antibody to mice. Thus a very early signal from oocytes might be necessary to promote proliferation of granulosal cells. Potential candidates might be growth differentiating factor 9 (GDF-9) (Dong et al., 1996), epidermal growth factor or its receptor (Singh et al., 1995) or a product from the $\mathrm{X}$ chromosome, since sheep that are homozygous for an $\mathrm{X}$-linked mutation $\left(\mathrm{Fec} \mathrm{X}^{\mathrm{1}}\right.$ ) contain primordial and primary follicles with enlarging oocytes (expressing c-kit) but with no corresponding increase in the number of granulosal cells (P. Smith, T. Lundy and K. P. McNatty, unpublished).

\section{Gonadotrophin receptors}

Follicle stimulating hormone (FSH) is unlikely to be a critical factor for initiating the growth of primordial follicles. There is convincing evidence from sheep, humans, cows and pigs that the gene for the FSH receptor (FSH-R) is not expressed until the follicle has reached the type 2-3 stage of development (Tisdall et al., 1995; Xu et al., 1995; Yuan et al., 1996; Oktay et al., 1997). At this and all

dark field views of ${ }^{35} \mathrm{P}$-labelled $\mathrm{p} 450 \mathrm{scc}$ antisense riboprobe hybridized to theca interna of a type 5 follicle. All sense probes showed no evidence of specific hybridization (see Tisdall et al., 1995 for methodology). The ovine LH-R cDNA was obtained from G. Niswender, Colorado State University, Fort Collins, CO and the bovine p450scc from M. Waterman, Vanderbilt University School of Medicine, Nashville, TN. Scale bars represent $(\mathrm{a}, \mathrm{b}, \mathrm{c}, \mathrm{d}) 80 \mu \mathrm{m} ;(\mathrm{e}, \mathrm{f}, \mathrm{g}, \mathrm{h}) 160 \mu \mathrm{m}$. 

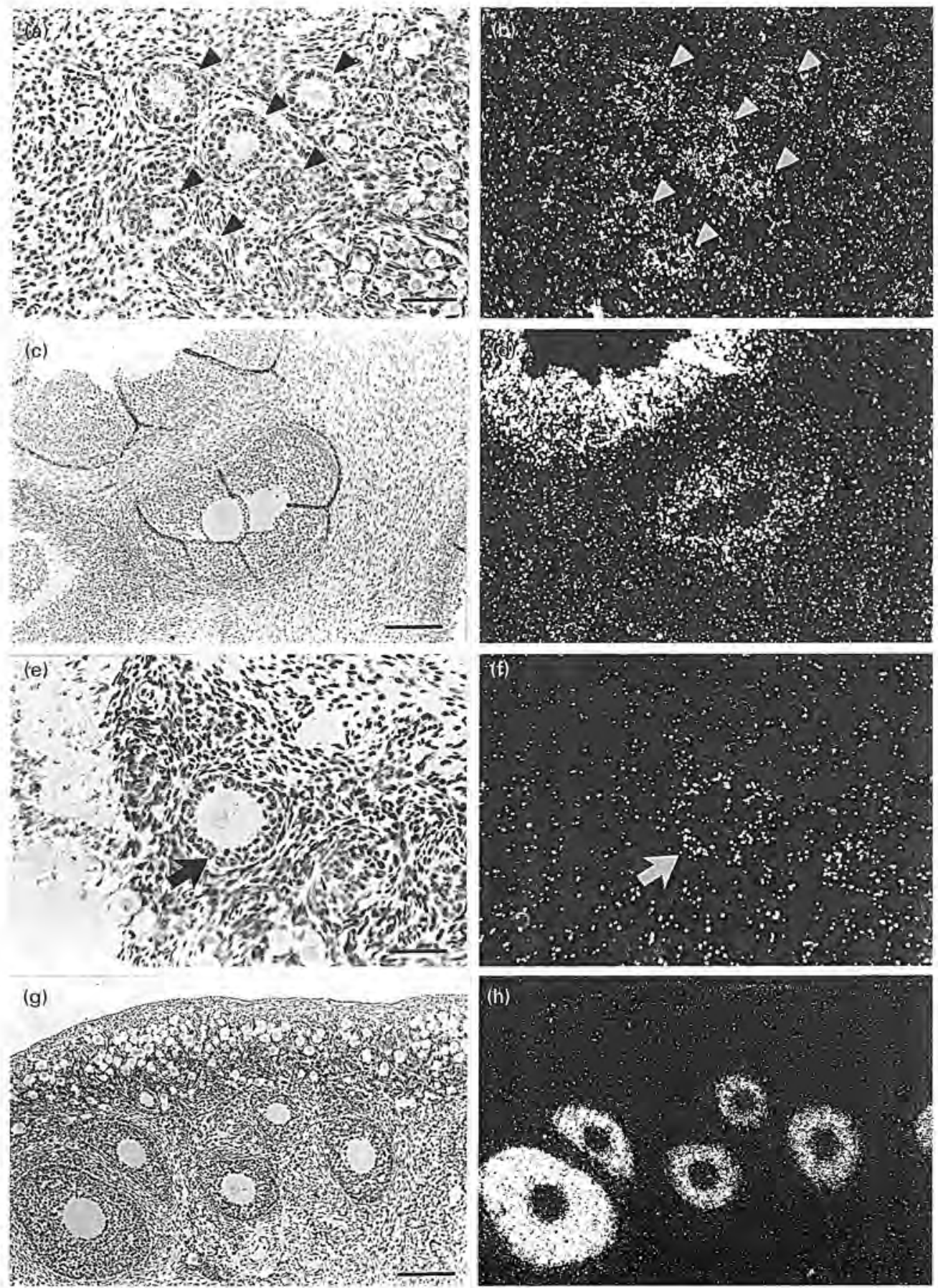

Fig. 3. Localization of inhibin and activin subunit mRNAs in small follicles of the sheep ovary: (a) light field and (b) dark field views of type 2 and 3 follicles (arrowheads) with evidence of hybridization of inhibin/activin $\beta_{\mathrm{v}}$ subunit antisense riboprobe to granulosal cells. Note there is no increase above background in type 1 follicles (b); (c) light field and (d) dark field views of type 5 and larger follicles with hybridization of inhibin/activin $\beta$ subunit antisense riboprobe to granulosal cells; (e) light field and ( $\mathrm{f}$ ) dark field views of a type 3 follicle (arrows) with hybridization of inhibin $\alpha$ subunit antisense 
subsequent stages of development FSH-R mRNA is localized exclusively to granulosal cells (Fig. 2). Autoradiographic analysis of ${ }^{225}$ I-labelled FSH binding to preantral follicles is consistent with the presence of FSH-R in granulosal cells of type 2-4 but not type 1 or 1a follicles (Wandji et al,, 1992a). It is likely that the FSH-R is functionally active during preantral development because culture of preantral bovine, hamster and human follicles in serum-free media supplemented with FSH leads to significant increases in the number of granulosal cells or uptake of BrdU or thymidine by granulosal cells (Roy and Greenwald, 1989; Hulshof ef al., 1995; Wandji et al., 1996a). Moreover, granulosal cells in large preantral-early antral follicles can synthesize cAMP or lactate in response to FSH in vitro (McNatty et al., 1992; Boland et al., 1993).

Although it can be demonstrated that FSH has stimulatory effects on granulosal cell proliferation and function in preantral follicles it is not an essential factor for proliferation of granulosal cells (Hirshfield, 1985) or the formation of a theca interna (Magarelli et al., 1996). FSH-deficient mice produced by gene targeting of embryo stem cells (Kumar et al., 1997) or hypohysectomized hamsters, rats or sheep all contain normally developing small follicles (Hirshfield, 1985; McNatty et al., 1990; Wang and Greenwald, 1993). Furthermore, slices of ovarian cortex from the cow cultured in media devoid of gonadotrophins led to an increase in the number of primary and small preantral follicles and a corresponding decrease in the number of primordial follicles (Wandji et al, 1996a; Braw-Tal and Yossefi, 1997) indicating that the initiation of follicular growth is likely to involve paracrine or autocrine rather than endocrine factors.

In sheep, the theca interna develops in type 3 follicles and in cattle in type 4 follicles (Braw-Tal and Yossefi, 1997; Lundy et al., 1998). Luteinizing hormone receptor (LH-R) mRNA is demonstrable in theca interna of type 4-5 preantral follicles of pigs, cows and sheep (Xu et al., 1995; Yuan et al., 1996; Fig. 2). In rodents, the mRNAs encoding the intra- and extracellular domains of the LH-R appear concomitantly with the appearance of differentiated thecal cells but increased expression of LH-R during follicular growth is a gonadotrophin-dependent event (Sokka et al., 1996; O'Shaughnessy et al., 1997). In cattle, pigs and sheep the mRNAs for $\mathrm{P} 450_{\text {scc }}$ and $\mathrm{P} 450_{17 \text {-hydroxylase }}$ enzymes are present in theca interna of type 4-5 follicles, which also synthesize androgens in vitro (Fig. 2; McNatty et al., 1986; Yuan et al., 1996). In domestic ruminants there is evidence that type 4-5 follicles have functional FSH-R and LH-R in granulosal cells and thecal cells, respectively, and that in ewes these follicles are capable of synthesizing progestins, androgens and oestrogens in vitro (McNatty et al., 1986; Yuan et al., 1996; Wandji et al., 1996b).

\section{Inhibin/activin subunits}

Inhibins and activins are dimeric growth factors of the transforming growth factor $\beta$ superfamily. The subunits inhibin $\alpha$, inhibin/activin $\beta_{A}$ and inhibin/activin $\beta_{B}$ together with the activin receptors type I, IIA and IIB are expressed in ovarian cells during follicular development (Roberts et al, 1993; Cameron et al., 1994). In sheep ovaries the mRNA and peptide for $\beta_{B}$ inhibin/activin subunit is first detected in granulosal cells of type 1a-3 follicles (Figs 1 and 3). The smallest follicles containing the $\beta_{\mathrm{B}}$ inhibin/activin peptide (using antisera clone C5; Groome et al., 1996) were those containing one layer of granulosal cells but with at least one cuboidal cell (Fig. 1). At later stages of growth the $\beta_{B}$ peptide was found increasingly in the zona pellucida although gene expression continued in granulosal cells (Fig. 1). However, no hybridization of the antisense $\beta_{\mathrm{B}}$ probe was noted in the oocyte, theca interna or interstitial cells. Unlike the early appearance of $\beta_{\mathrm{B}} \mathrm{mRNA}$ in granulosal cells that for inhibin/activin $\beta_{A}$ was not found until follicles reached the type 5 stage of growth (Torney et al., 1989; Braw-Tal, 1994; Tisdall et al., 1994). At this stage and thereafter $\beta_{A}$ inhibin/activin mRNA was localized exclusively to granulosal cells (Fig. 3 ). In contrast to the $\beta_{A}$

riboprobe to granulosal cells; (g) light field and (h) dark field views of types 3-5 but not type 1-2 follicles with hybridization of follistatin subunit antisense riboprobe to granulosal cells. For details on $\alpha$-inhibin and $\beta_{\mathrm{A}}$ inhibin/activin in situ procedures and ${ }^{33} \mathrm{P}$-labelled riboprobes see Braw-Tal et al. (1994) and Tisdall et al. (1994). The $\beta_{\mathrm{B}}$ cDNA was supplied by $\mathrm{R}$. Rodgers (Flinders University of South Australia, SA, Australia). Scale bars represent $(\mathrm{a}, \mathrm{b}, \mathrm{e}, \mathrm{f}) 80 \mu \mathrm{m} ;(\mathrm{c}, \mathrm{d}, \mathrm{g}, \mathrm{h}) 160 \mu \mathrm{m}$. 

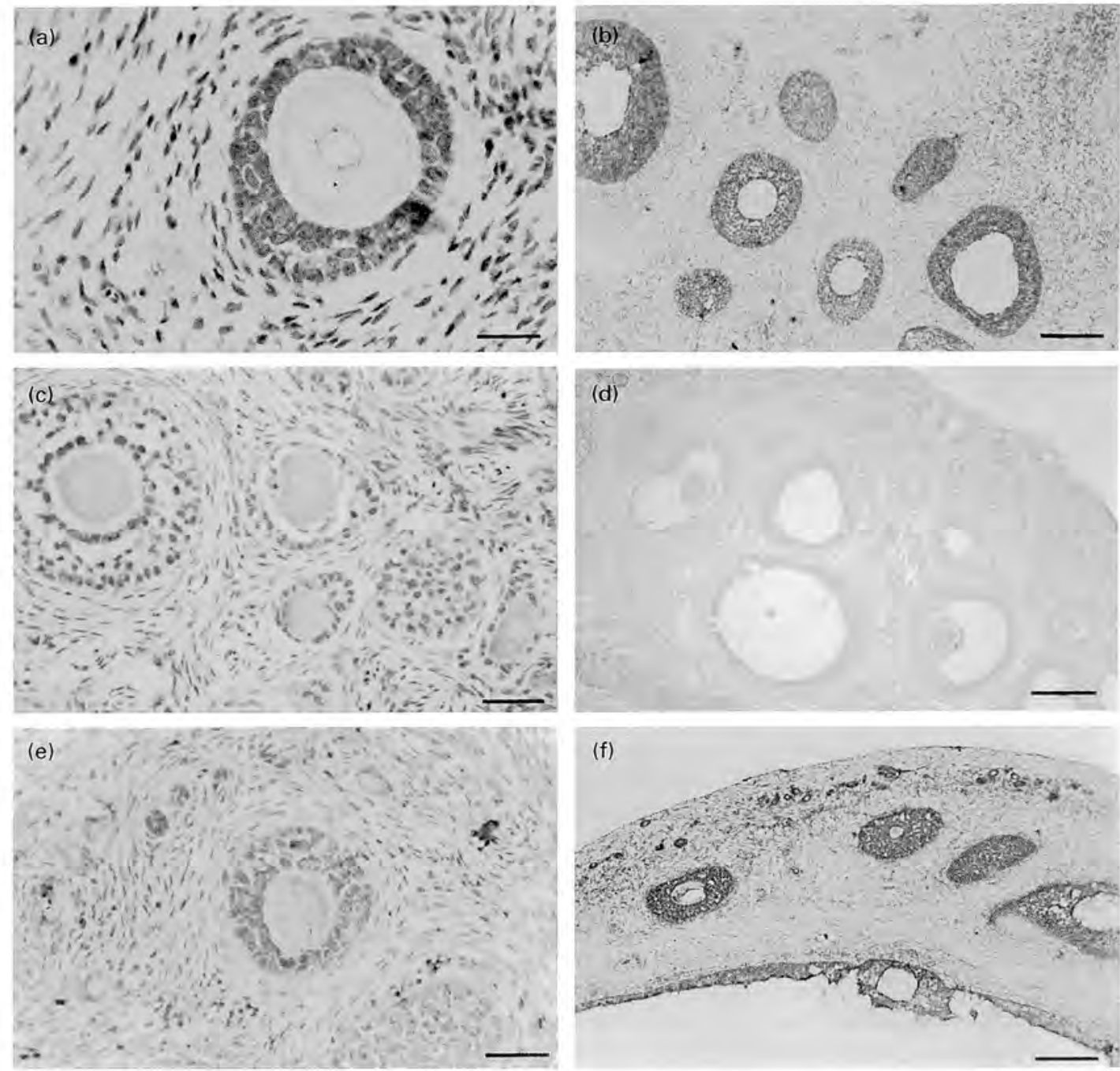

Fig. 4. Immunostaining for inhibin and/or activin subunits and follistatin in ovarian follicles of the sheep ovary: inhibin- $\alpha$ subunit immunostaining in type 3 follicle (a) and in type 4-5 follicles (b). Note intense immunostaining in granulosal cells and light immunostaining in some oocytes. (c,d) Inhibin/activin $\beta_{\mathrm{A}}$ subunit immunostaining in granulosal cells and oocytes of small (type 2-5) and both small and large antral follicles; (e,f) follistatin immunostaining in oocytes and granulosal cells of both preantral and antral follicles. For details on histological and immunohistochemical procedures see legend to Fig. 1. For details on the inhibin- $\alpha$ subunit antisera (clone R1) and $\beta_{\mathrm{A}}$ inhibin/activin antisera (clone E4) see Groome et al. (1990) and Groome and Lawrence (1991). The follistatin antisera (RGAS005) was generated against a 315 amino acid recombinant ovine follistatin (RGAS006) and both products were produced at the Wallaceville Animal Research Centre. Scale bars represent (a) $26.7 \mu \mathrm{m}$; (b, d, f) $160 \mu \mathrm{m}$; (c, e) $40 \mu \mathrm{m}$.

inhibin/activin mRNA results, immunohistochemical studies (using antisera Clone E4; Groome and Lawrence, 1991) localized the $\beta_{\mathrm{A}}$ inhibin/activin peptide to oocytes as well as to granulosal cell at all stages of follicular growth (for example primordial, primary, preantral and antral growth) (Fig. 4). One interpretation of this finding is that the monoclonal antibody to $\beta_{\mathrm{A}}$ peptide binds $\beta_{\mathrm{A}}$ inhibin/activin subunit which originated from an extragonadal source via the blood supply. 
Collectively these results provide evidence for the presence of $\beta$ inhibin/activin subunit peptides in oocytes or granulosal cells of preantral follicles.

Inhibin $\alpha$ subunit mRNA was first observed in granulosal cells of developing ovine follicles with two or three layers of granulosal cells (Fig. 1). Thereafter the hybridization signal increased exclusively in granulosal cells of both preantral and antral follicles (Braw-Tal, 1994). Similarly immunohistochemical studies with an inhibin $\alpha$-subunit antibody (Clone R1; Groome et al., 1990) demonstrated specific binding to granulosal cells of follicles with two or three layers of granulosal cells with no binding to theca interna, although a low level of binding was associated with the oocyte (Fig. 4).

The presence of $\beta$ activin/inhibin subunits at several sites may be indicative of the presence of activin receptors in both oocytes and granulosal cell or other factors that bind the $\beta$ activin/inhibin subunits (for example follistatin). Of interest is the finding that type $1 \mathrm{a}-2$ follicles represent the only stages of development in which $\beta_{B}$ activin/inhibin expression occurs in the absence of the $\alpha$ inhibin subunit. Mice homozygous for a deletion of the inhibin $\alpha$ subunit gene secrete large amounts of activin A and B and develop sex cord-stromal tumours (Matzuk et al., 1996); these tumours in the female may arise from uncontrolled proliferation of granulosal cells. In normal animals the rate of proliferation of granulosal cells may be influenced in part by the endogenous production of inhibin in type 3 and larger follicles thereby blocking the action of activin via the type II activin receptor (Martens et al., 1997). In domestic ruminants it remains to be determined when the activin receptors first appear and whether activin B has an important role in either upregulating FSH receptors (see Findlay, 1993 for review) or in promoting the development of a type 3 follicle.

\section{Follistatin}

Overexpression of follistatin in transgenic mice inhibits follicular growth at the primary and subsequent stages of development (Guo et al., 1998). Thus follistatin may regulate the actions of activin or other members of the transforming growth factor $\beta$ (TGF $\beta$ ) family (for example GDF-9).

In sheep, follistatin gene expression was first observed in granulosal cells of type 3 follicles (Braw-Tal, 1994; Braw-Tal et al., 1994) (Fig. 3). Thereafter it was observed in almost all preantral, and non-atretic antral follicles throughout their different growth phases. Follistatin protein was first observed in granulosal cells of type 2 follicles and at subsequent phases of growth. The earlier detection of protein over mRNA for follistatin may be the result of differences in sensitivities in the methods used or to the protein originating from an extracellular source. In addition, follistatin peptide can be localized to oocytes in types 1-5 follicles as well as large preantral follicles (Dr R. Braw-Tal, personal communication; Fig. 4).

Collectively the immunohistochemical data infer that follistatin and activin and perhaps to a lesser extent inhibin are associated with the oocyte throughout follicular growth. In this context, exposure of oocytes to excess activin A stimulates meiotic maturation in follicle-enclosed oocytes and oocyte degeneration in immature follicles (Woodruff et al., 1990; Erickson et al., 1995). During preantral and early antral follicular growth, follistatin may act as a binding protein to prevent premature oocyte maturation. It is worth noting for most follicular growth phases that the $\beta_{\mathrm{A}}$ activin/inhibin peptide and follistatin are consistently co-localized where the two peptides have been studied together. In contrast the $\beta_{\mathrm{B}}$ activin/inhibin peptide does not co-localize with follistatin. Instead the $\beta_{\mathrm{B}}$ subunit is strongly associated with both the oocyte plasma membrane and zona pellucida inferring a different mechanism of action.

\section{TGF $\beta$ and FGF}

Transforming growth factor $\beta$ is known to be produced by bovine thecal cells and to influence granulosal cell proliferation (Skinner et al., 1987; Wandji et al., 1996b). In the sheep ovary TGF $\beta_{1}$ mRNA was observed in stromal/interstitial tissues and first observed in theca interna in type 4 or 5 follicles, whereas TGF $\beta_{3}$ was noted mainly in smooth muscle cells around blood vessels in the theca 

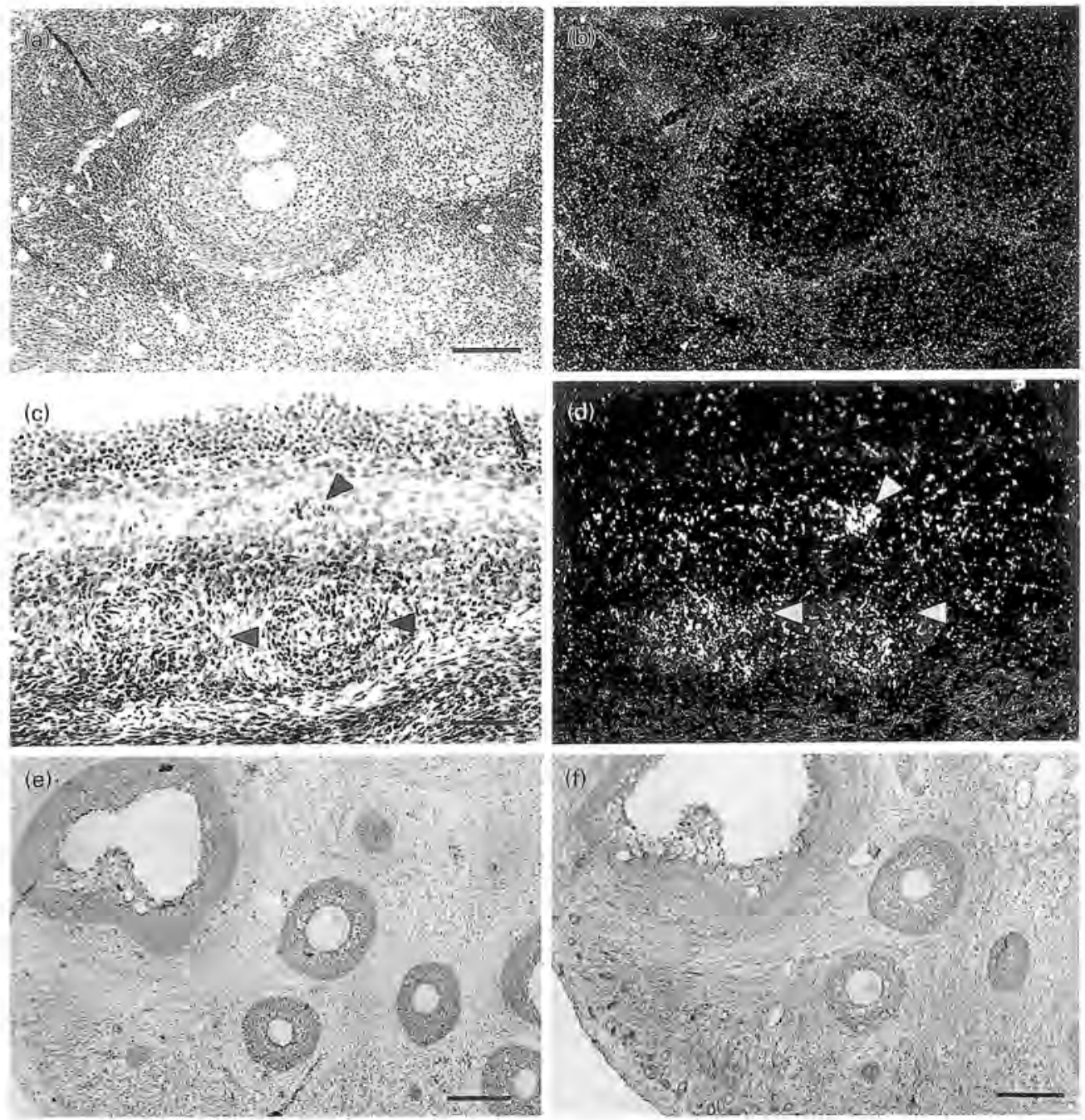

Fig. 5. Localisation of transforming growth factor $\beta$ in the sheep ovary: (a) light field and (b) dark field views of a type 5 follicle with evidence of hybridization of the ${ }^{32} \mathrm{P}^{\mathrm{P}}$-labelled TGF $\beta_{1}$ antisense riboprobe to theca interna and areas of the adjacent stroma/ interstitium but not granulosal cells; (c) light field and (d) dark field views of large antral follicle with evidence of hybridization of the ${ }^{33} \mathrm{P}$-labelled TGF $\beta_{3}$ antisense riboprobe to smooth muscle cells of blood vessels (arrowheads) and thecal interna but not granulosal cells; (e) immunostaining for TGF $\beta_{1}$ in oocytes, granulosal cells of preantral and antral follicles and to a lesser extent in the theca interna and interstitium; (f) immunostaining for TGF $\beta_{29}$ indicating widespread localization in the ovary. The TGF $\beta_{1}$ riboprobe was from an RT-PCR derived 1172 bp ovine cDNA for the complete coding region. The TGF $\beta_{3}$ riboprobe was from an RT-PCR derived 960 bp ovine cDNA. All sense probes showed no evidence of specific hybridization. The TGF $\beta_{1}$ antibody (clone TB-21) was obtained from Anogen Inc, Mississauga, Ontario and the anti-TGF $\beta_{23}$ (clone AB-1) from Oncogene Science Inc, Uniondale, NY. For further details on immunohistochemical procedures see Fig. 1. Scale bars represent $(a, b) 80 \mu \mathrm{m} ;(\mathrm{c}, \mathrm{d}) 73 \mu \mathrm{m} ;(\mathrm{e}, \mathrm{f}) 160 \mu \mathrm{m}$.

layer (Fig. 5). The pattern of TGF $\beta_{2}$ expression was similar to that of TGF $\beta_{1}$ (D. Tisdall, unpublished). By contrast TGF $\beta_{1}$ peptide was widespread throughout the ovary (Fig. 5): it was observed in oocytes, especially in primordial follicles and it was prominent in granulosal cells at the type 2 stage of development and to a lesser extent in the theca interna. Immunostaining with antibody that 
(a)

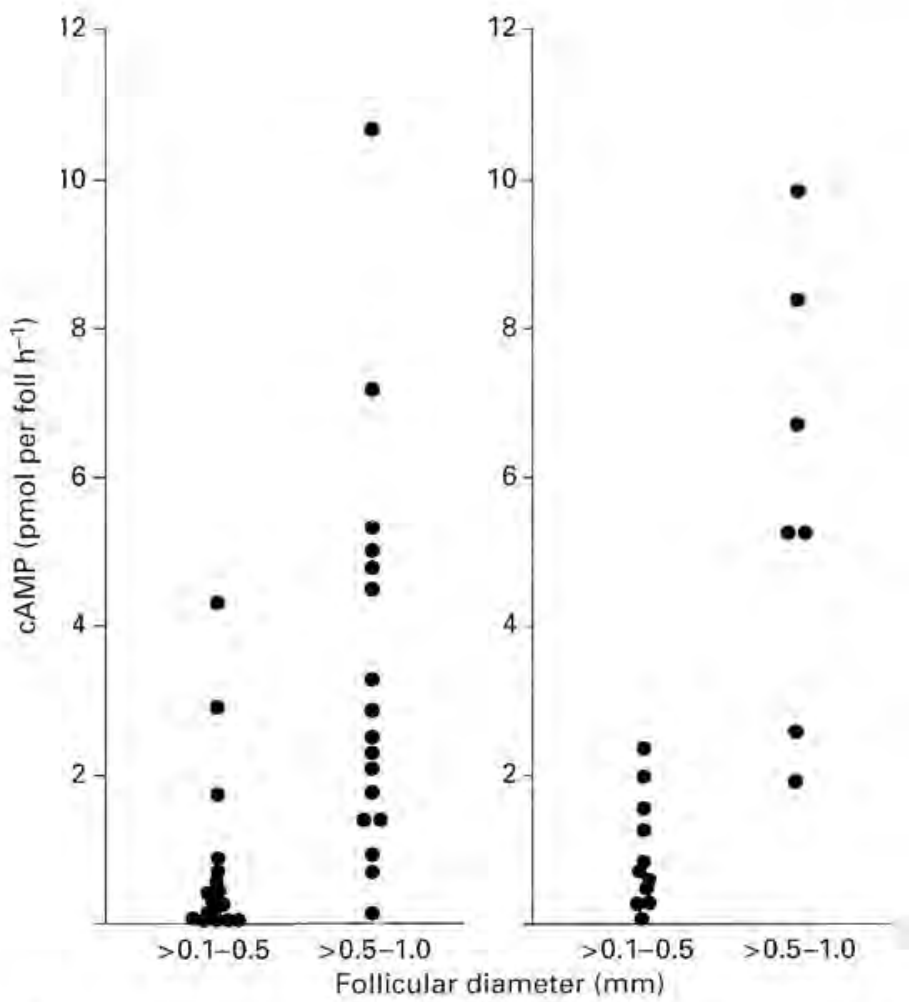

Fig. 6. The cyclic adenosine 3,5'-monophosphate (cAMP) responses of individual large preantral-early antral ovine follicles (follicle types 4 and 5) dissected from an individual (a) intact or (b) long-term (i.e. 60 days) hypophysectomized ewe. Each follicle from each ewe was incubated separately for $1 \mathrm{~h}$ in $1 \mathrm{ml}$ Dulbecco's phosphate-buffered saline $+0.1 \% \mathrm{w} \mathrm{v}^{-1}$ bovine serum albumin + ovine LH (NIH-LH-S23, $1 \mu \mathrm{g} \mathrm{ml}^{-1}$ ) + and FSH (NIH-FSH-S11, $1 \mu \mathrm{g} \mathrm{ml}^{-1}$ ) (see McNatty et al., 1986 for experimental details).

recognizes TGF $\beta_{2}$ and TGF $\beta_{3}$ but not TGF $\beta_{1}$ indicated widespread distribution of these peptides throughout the ovary (see Fig. 5).

Granulosal cells in culture express the gene encoding fibroblast growth factor 2 (FGF-2) (Neufield et al., 1987). However, the ontogeny of FGF-2 gene expression in developing follicles and other ovarian cellular sources is not well understood. Immunocytochemical studies reveal that FGF2 peptide is widespread throughout the bovine ovary being present in oocytes of primordial and primary follicles, granulosal cells of large preantral and antral follicles, theca interna, ovarian surface epithelium and smooth muscle cells surrounding blood vessels (Van Wezel et al., 1995). Moreover FGF receptors are found in granulosal cells of type 2 follicles (Wandji et al., 1992b).

In addition to the localization of TGF $\beta$ s and FGF-2 to oocytes of primordial and primary follicles, epidermal growth factor (EGF) has been localized to oocytes of primordial follicles of hamsters and pigs and TGF $\alpha$ to oocytes of primary follicles (Roy and Greenwald, 1990, Singh et al., 1995). Collectively, therefore, oocytes in primordial follicles appear to be bathed in growth factors, some of 
which are likely to have stimulatory effects on granulosal cells (i.e. stem cell factor, activin, FGF-2 and EGF), whereas others are likely to be inhibitory (follistatin, TGFßs) (Gospodarowicz et al., 1986; Li et al., 1995; Wandji et al., 1996b; Guo et al., 1998). The relative importance of these growth factors or their receptors in the initiation of follicular growth remains to be determined.

\section{Hierarchical Development}

In domestic ruminants, initiation of follicular growth begins in late fetal life and continues without interruption during infancy, pregnancy, lactation and the oestrous cycle. From studies in rodents it has been proposed that follicles grow sequentially and continue to grow until they either become atretic or ovulate (Peters et al., 1975). In studies of granulosal cell populations and steroid concentrations in follicular fluid of antral follicles from sheep, cows and humans it is evident that, at any time, no two follicles share an identical cell composition or steroid microenvironment (for example McNatty, 1978). These data are consistent with the notion that follicles develop in a hierarchical manner. Further evidence to support this notion was obtained from examining the gonadotrophin-induced cyclic AMP responses of late preantral-early antral follicles isolated from either hypophysectomized or control ewes (Fig. 6). These data also infer that preantral follicles may develop in a hierarchical manner and that this pattern of development is, at least in part, independent of gonadotrophins.

\section{Conclusions}

The growth of a primordial follicle to the early antral phase involves eight doublings of the population of granulosal cells and a 3-4-fold enlargement of the oocyte. In domestic ruminants most, if not all, of these growth phases can occur in the absence of gonadotrophins. However, based upon evidence from animal mutants, many of these growth phases are dependent on locally produced growth factors or receptors including c-kit, stem cell factor, members of the transforming growth factor superfamily (for example $\beta_{\Lambda}$ inhibin/activin, $\alpha$-inhibin, GDF-9) and follistatin. The evidence from studies in domestic ruminants shows that these growth factors together with receptors for both growth factors and gonadotrophins are expressed during early follicular growth in a stage- and cell-specific manner.

\section{References}

Boland NI, Humpherson PG, Leese HJ and Gosden RG (1993) Pattern of lactate production and steroidogenesis during growth and maturation of mouse ovarian follicles in vitro. Biology of Reproduction 48 798-806

Braw-Tal R (1994) Expression of mRNA for follistatin and inhibin/activin subunits during follicular growth and atresia Journal of Molecular Endocrinology 13 253-264

Braw-Tal R and Yossefi S (1997) Studies in vizo and in tritro on the initiation of follicle growth in the bovine ovary Journal of Reproduction and Fertility 109 165-171

Braw-Tal R, Tisdall DJ, Hudson NL, Smith P and McNatty KP (1994) Follistatin but not $\alpha$ or $\beta_{A}$ inhibin subunit mRNA is expressed in ovine fetal ovaries in late gestation Journal of Molecular Endocrinology 13 1-9

Cameron VA, Nishimura E, Mathews LS, Lewis KA, Sawchenkko PE and Vale WW (1994) Hybridization histochemical localization of activin receptor subtypes in rat brain, pituitary, ovary and testis Endocrinology 134 799-808

Clark DE, Tisdall DJ, Fidler AE and McNatty KP (1996)
Localization of mRNA encoding c-kit during the initiation of folliculogenesis in ovine fetal ovaries Journal of Reproduction and Fertility 106 329-335

Dong J, Albertini DF, Nishimori K, Kumar TR, Lu N and Matzuk M (1996) Growth differentiation factor-9 is required during early ovarian folliculogenesis Nalure 383 531-535

Erickson GF, Kokka S and Rivier C (1995) Activin causes premature superovulation Endocrinology $1364804-4813$

Findlay JR (1993) An update on the roles of inhibin activin and follistatin as local regulators of folliculogenesis Biology of Reproduction 48 15-23

Gospodarowicz D, Neufield G and Schweigener L (1986) Fibroblast growth factor Molecular Cellular Endocrinology $46187-204$

Groome N and Lawrence M (1991) Preparation of monoclonal antibodies to the beta $A$ subunit of ovarian inhibin using a synthetic peptide immunogen Hybridoma 10 309-316

Groome N, Hancock J, Betteridge A, Lawrence M and Craven R (1990) Monoclonal and polyclonal antibodies reactive with 
the I-32 amino terminal sequence of the alpha subunit of human $32 \mathrm{~K}$ inhibin Hybridoma $93 \mathrm{I}-42$

Groome NP, Illingworth P'J, O'Brien M, Pai R, Rodger FE, Mather JP and McNeilly AS (1996) Measurement of dimeric inhibin $B$ throughout the human menstrual cycle Joumal of Clinical Endocrinology and Metabolism 81 1401-1405

Gundersen HJG (1988) The nucleator Journal of Microscopy 151 3-21

Guo Q, Kumar T, Woodruff T, Hadswell L, De Mayo F and Matsuk M (1998) Overexpression of mouse follistatin causes reproductive defects in transgenic mice Molecular Endocrinology 12 96-106

Hirshfield AN (1985) Comparison of granulosa cell proliferation in small follicles of hypophysectomized, prepubertal and mature rats Biology of Reproduction 32 979-987

Hirshfield AN and De Santi AM (1995) Patterns of ovarian cell proliferation in rats during the embryonic period and the first three weeks post partum Biology of Reproduction 53 1208-1221

Hsu SM, Raine L and Fanger H (1981) Use of a activin-biotin-peroxidase complex (ABC) in immunoperoxidase techniques: a comparison between $\mathrm{ABC}$ and unlabelled antibody (MAP) procedures journal of Histochemistry and Cytochemistry 29 577-580

Huang E, Manova K, Packer Al, Sanchez S, Bachvarova RF and Besmer P (1993) The murine steel panda mutation affects kit ligand expression and growth of early ovarian follicles Developmental Biology 157 100-109

Hulshof SCJ, Figueiredo JR, Beckers JE, Bevers MM, van der Donk JA and van den Hurk R (1995) Effects of fetal bovine serum, FSH and $17 \beta$-estradiol on the culture of bovine preantral follicles Theriogenology 44 217-226

Kumar T, Wang Y, Lu N and Matzuk M (1997) Follicle stimulating homone is required for ovarian follicle maturation but not male fertility Nature Genetics 15 201-204

Li R, Phillips DM and Mather JP (1995) Activin promotes ovarian follicular development in vitro, Endocrinology 136 849-856

Lundy T, Smith P, O'Connell A, Hudson NL and McNatty KP (1999) Populations of granulosa cells in small follicles of the sheep ovary Joumal of Reproduction und Feriility $\mathbf{1 1 5}$ 251-262

McNatty KP (1978) Cyclic changes in antral fluid hormone concentrations in humans. In Clinics in Endocrinology and Metabolism Vol. 7 no 3 pp 577-600 Eds GT Ross and MB Lipsett. WB Saunders Co. Ltd, London

McNatty KP, Kieboom LE, McDiarmid J, Heath DA and Lun S (1986) Adenosine cyclic $3^{\prime}, 5^{\prime}$-monophosphate and steroid production by small ovarian follicles from Booroola ewes with and without a fecundity gene Ioumal of Reproduction and Fertility $76471-480$

McNatty KP, Heath DA, Hudson N and Clarke IJ (1990) Effect of long-term hypophysectomy on ovarian follicle populations and gonadotrophin-induced adenosine cyclic 3, $5^{\prime}$-monophosphate output by follides from Booroola ewes with or without the $\mathrm{F}$ gene Journal of Reproduction and Fertility $90515-522$

McNatty KP, Smith P, Hudson NL, Heath DA, Lun S and O W-S (1992) Follicular development and steroidogenesis. In Local Regulation of Ovarian Function pp 21-38 Eds N-O Sjoberg, L Hamberger, PO Jansen, Ch Owman and HIT Coelingh-Bennink. Parthenon Publishing, Park Ridge, New Jersey
Magarelli P, Zachow R and Magoffin D (1996) Developmental and hormonal regulation of rat theca-cell differentiation factor secretion in ovarian follicles Biology of Reproduction $55416-420$

Martens JW, de Winter JP, Timmerman MA, McLuskey A, van Schauk RH, Themmen AP and de Jong FH (1997) Inhibin interferes with activin signalling at the level of the activin receptor complex in Chinese hamster ovary cells Endocrinology $1382928-2936$

Matzuk M, Kumar T, Shou W, Coerver K, Lau A, Behringer R and Finegold M (1996) Transgenic models to study the roles of inhibins and activins in reproduction, oncogenesis and development Recent Progress in Hormone Research 51 123-137

Motro B and Bernstein A (1993) Dynamic changes in ovarian ckit and steel expression during the estrous reproductive cycle Developmental Dynamics 197 69-79

Neufield G, Ferrara N, Schweigerer L, Mitchell R and Gospodarowicz D (1987) Bovine granulosa cells produce basic fibroblast growth factor Endocrinology 121 597-603

Oktay K, Schenken R and Nelson JT (1995) Proliferating cell nuclear antigen marks the initiation of follicular growth in the rat Biology of Reproduction 53 295-301

Oktay K, Briggs D and Gosden RG (1997) Ontogeny of folliclestimulating hormone receptor gene expression in isolated human follicles Journal of Clinical Endocrinology and Metabolism 82 3748-3751

O'Shaughnessy PJ, McLelland D and McBride MW (1997) Regulation of luteirizing hormone-receptor and folliclestimulating hormone-receptor messenger ribonucleic acid levels during development in the neonatal mouse ovary Biology of Reproduction $\mathbf{5 7} 602.608$

Peters H, Byskov AG, Himelstein-Braw R and Faber M (1975) Follicle growth: the basic event in the mouse and humar ovary Journal of Reproduction and Fertility 45 559-566

Roberts VJ, Barth S, el-Roeiy and Yen SS (1993) Expression of inhibin/activin suburits and follistatin messenger ribonucleic acids and proteins in ovarian follicles and the corpus luteum during the human menstrual cycle Joumal of Clinical Endocrinology and Metabolism 77 1402-1410

Roy SK and Greenwald GS (1989) Hormonal requirements for the growtly and differentiation of hamster preantral follicles in long-term culture Journal of Reproduction and Feritility 87 103-114

Roy SK and Greenwald G (1990) Immunohistochemical localization of epidermal growth factor-like activity in the hamster ovary with a polyclonal antibody Endocrinology 126 1309-1317

Singh B, Rutledge JM and Armstrong DT (1995) EpidermaI growth factor and its receptor gene expression and peptide localisation in porcine ovarian follicles Moleculder. Reproduction and Development 40391-399

Skinner MK, Keshi-Oja J, Osteen K and Moses HL (1987) Ovarian theca cells produce transforming growth factor-beta which can regulate granulosa cell growth and differentiation Endocrinology 121 786-792

Smith P, O W-S, Corrigan KA, Smith T, Lundy T, Davis GH and McNatty KP (1997) Ovarian morphology and endocrine characteristics of female sheep fetuses that are heterozygous or homozygous for the Inverdale prolificacy gene (Fec ${ }^{1}$ ) Biology of Reproducfion 57 1183-1192

Sokka TA, Hamalainen TM, Kaipa A, Warren DW and Huhtaniemi IT (1996) Development of luteinizing hormone action in the perinatal rat ovary Biology of Reproduction $55663-670$ 
TisdaIl DJ, Hudson N, Smith P and McNatty KP (1994) Localization of ovine follistatin and $\alpha$ and $\beta_{A}$ inhibin mRNA in the sheep ovary during the oestrous cycle Journal of Molecular Endocrinology 12 18I-193

Tisdall DJ, Watanabe K, Hudson NL, Smith P and McNatty KP (1995) FSH receptor gene expression during ovarian follicle development in sheep Journal of Molecular Endocrinology 15 273-281

Tisdall DJ, Quirke LD, Smith P and McNatty KP (1997) Expression of the ovine stem cell factor during folliculogenesis in late fetal and adult ovaries Journal of Molecular Endocrinology 18 127-135

Torney AH, Hodgson YM, Forage R and de Kretser DM (1989) Cellular localization of inhibin mRNA in the bovine ovary by in situ hybridization Journal of Reproduction and Fertility $86391-399$

van Wezel IL. and Rodgers RJ (1996) Morphological characterization of bovine primordial follicles and their environment in vizo. Biology of Reproduction 55 1003-1011

van Wezel IL, Umapathysivam K, Tilley WD and Rodgers RJ (1995) Immunohistochemical localization of basic fibroblast growth factor in bovine ovarian follicles Molecular and Cellular Endocrinology 115 133-140

Wandji S-A, Pelletier G and Sirard M-A (1992a) Ontogeny and cellular localization of ${ }^{125}$ I-labelled insulin-like growth factor-I, ${ }^{125} \mathrm{I}$-labelled follicle-stimulating hormone and ${ }^{125} \mathrm{I}$ labelled human chorionic ganadotropin binding sites in ovaries from bovine fetuses and neonatal calves Biology of Reproduction 47 814-822

Wandji S-A, Pelletier G and Sirad M-A (1992b) Ontogeny and cellular localization of ${ }^{125} \mathrm{I}$-labelled basic fibroblast growth factor and 125 -labelled epidermal growth factor binding sites in ovaries from bovine fetuses and neonatal calves Biology of Reproduction 47 807-813

Wandji S-A, Sosen V, Voss AK, Eppig JJ and Fortune JE (1996a) Initiation in vitro of growth of bovine primordial follicles Biology of Reproduction 55 942-948

Wandji S-A, Eppig JJ and Fortune JE (1996b) FSH and growth factors affect the growth and endocrine functions in vitro of granulosa cells of bovine preantral follicles Theriogenology 45 817-832

Wang X-N and Greenwald GS (1993) Hypophysectomy of the cyclic mouse. 1. Effects on folliculogenesis, oocyte growth and follicle-stimulating hormone and human chorionic gonadotrophin receptors Biology of Reproduction 48 585-594

Woodruff TK, Lyan RJ, Hansen SE, Rice GC and Mather JP (1990) Inhibin and activin locally regulate rat ovarian folliculogenesis Endocrinology 127 3196-3205

Xu ZZ, Garverick HA, Smith GW, Smith MF, Hamilton SA and Young-Quist RS (1995) Expression of follicle-stimulating hormone and luteinizing hormone receptor méssenger ribonucleic acids in bovine follicles during the first follicular wave Biology of Reproduction 53 951-957

Yuan W, Lucy MC and Smith MF (1996) Messenger ribonucleic acid for insulin-like growth factors-1 and -11, insulin-like growth factor binding protein-2, gonadotropin receptors, and steroidogenic enzymes in porcine follicles Biology of Reproduction 55 1045-1054

Yoshida H, Takakura N, Kataoka H, Kunisada T, Okamura $\mathrm{H}$ and Nishikawa S-I (1997) Stepwise requirement of c-kit tyrosine kinase in mouse ovarian follicle development Developmental Biology 184 122-137 